\title{
The role of tissue factor in normal pregnancy and in the development of preeclampsia: A review
}

\author{
Jana Prochazkovaa , Ludek Slavika, Jana Ulehlovaa, Martin Prochazka ${ }^{\mathrm{b}, \mathrm{c}}$
}

\begin{abstract}
Background. Tissue factor (TF) is a key element for normal gestation, especially in the first trimester. TF levels are hence raised in pregnancy, producing an adaptive hypercoagulable state. Potentiated hypercoagulability however, is associated with disorders of pregnancy such as pre-eclampsia but the results of TF and its inhibitor, tissue factor pathway inhibitor (TFPI), measurement, in pre eclampsic women are ambiguous and the data conflicting. This review covers the current knowledge status of the role of TF assessment in pregnancy with a focus on its diagnostic utility. Methods. A review of the literature using the following key words: tissue factor, thrombosis, inflammation, pregnancy, preeclampsia.

Results. The published literature shows raised and unchanged TF levels in various studies of pre-eclampsia along with equally conflicting data for TFPI. The various study designs and methods used in these studies makes valid comparison difficult. Meta analysis of 34 randomized trials showed that low-dose aspirin in early phases of gravidity (starting from the 16th week or earlier) significantly reduces the incidence of preeclampsia.

Conclusions. Overall, the results of the literature search together with knowledge of the structure and biological effects of TF, suggest that measuring the level of plasma TF/TFPI is not ideal for determining the actual levels of TF in the uteroplacental circulation. The current view that endothelial dysfunction is the trigger for preeclampsia, suggests that aspirin may be an effective prophylaxis. Further research will be necessary: measuring the expression of tissue factor on monocytes using flowcytometry and comparing the development of this expression during normal pregnancy and pregnancy complicated by preeclampsia, for example. Another possibility is immunohistochemical determination of the level of TF expression directly in placental tissue.
\end{abstract}

Key words: tissue factor, thrombosis, inflammation, pregnancy, preeclampsia

Received: May 3, 2014; Accepted with revision: November 13, 2014; Available online: December 22, 2014 http://dx.doi.org/10.5507/bp.2014.061

${ }^{a}$ Department of Hemato-oncology, University Hospital Olomouc and Faculty of Medicine and Dentistry, Palacky University Olomouc, Czech Republic

${ }^{b}$ Department of Obstetrics and Gynecology, University Hospital Olomouc and Faculty of Medicine and Dentistry, Palacky University Olomouc

'Department of Midwifery, Faculty of Health Sciences, Palacky University Olomouc

Corresponding author: Martin Prochazka, e-mail: martin.prochazka@fnol.cz

\section{TISSUE FACTOR - STRUCTURE AND ORGANS EXPRESS}

Tissue factor (TF), also called factor III, is a transmembrane glycoprotein weighing $46 \mathrm{kDa}$. It is an integral part of the cell wall in various tissues and released when cell wall integrity is disrupted. TF may be detected on the surface of activated endothelial cells, leukocytes and thrombocytes ${ }^{1}$. It is composed of an extracellular domain containing 219 aminoacids, a transmembrane domain comprising 23 aminoacids and an intracellular domain containing 21 aminoacids ${ }^{2,3}$. The extracellular domain has a receptor site for binding to F VII/VIIa complex (factor VII and activated factor VII complex). The intracellular domain is the signal site regulating TF expression ${ }^{4}$.

Individual organs express varying quantities of TF. Its greatest expression is found in brain (astrocytes), placenta (trophoblast cells) and lungs (alveoli), a moderate amount in heart, kidneys, intestines, testes and uterus and $\mathrm{t}$ the lowest expression seen in spleen, thymus, skeletal muscle and liver ${ }^{5-7}$. Most TF circulating in the blood is expressed on blood elements- thrombocytes and their microparticles, granulocytes, monocytes, and macrophages; a smaller amount of TF in plasma is the product of endothelial cells and circulates in the form of endothelial microparticles or as soluble TF (ref. ${ }^{1,8,9}$ ). Under physiological conditions, this amount is very low compared with the amount contained in the vascular wall, especially in smooth muscle cells and adventitial fibroblasts ${ }^{10}$. The level of expression on blood cells and endothelial cells significantly increases on damage or activation. TF may be detected on the cell surface as the markers CD 142 or CD 16. The amount of circulating tissue factor measured by the ELISA method in healthy individuals ranges from 149-172 pg/mL (ref. ${ }^{11}$ ). Membrane-bound TF is released upon disruption of the integrity of the vascular wall or upon cell activation due to mechanical damage, inflammation or atherosclerosis. 


\section{TISSUE FACTOR - BIOLOGICAL FUNCTIONS}

Tissue factor, specifically its extracellular domain, in contrast to other elements in the coagulation cascade, does not require enzymatic cleavage for its activation. TF activation on cell surfaces and particles containing TF in blood and damaged tissues occurs due to a change in their cell membrane. During this change, phospholipids are transferred to the external membrane surface (flipflop mechanism) following stimulation or cell damage, which leads to the uncovering of the receptor site for $F$ VII in the TF extracellular domain ${ }^{12}$. Tissue factor initiates blood clotting by gradual activation of inactive zymogens of F VII, X and II to active serine proteases VIIa, Xa and IIa (the "external pathway" of the coagulation cascade in the traditional sense). This leads to the cleavage of fibrinogen and the formation of fibrin deposits with subsequent activation of other components of the coagulation cascade (primarily F IX, and hence the "internal pathway" of the coagulation cascade), thrombocytes and also protease-activated receptors (PAR) (ref. $\left.{ }^{13}\right)$. The TF intracellular domain with signaling function leads to a number of biological "noncoagulatory" processes in cells on whose surface binding of TF to F VII occurs, such as the synthesis of cytokines, adhesion molecules and growth factors. These products play a key role during inflammation, wound healing, angiogenesis, apoptosis, cell migration, embryo development, but also in the growth and metastasis of tumors ${ }^{14,15}$.

The gene for TF synthesis is located on chromosome 1. Tissue factor is the only coagulation factor in which a congenital deficiency has not been described which supports the assumption that this condition is incompatible with life ${ }^{13}$. Tissue factor is a key product of blood clotting in all tissues; in addition, its high levels of expression in vitally important organs (brain, lungs, heart and placenta) most likely ensure additional hemostatic protection for these organs ${ }^{13}$.

Tissue factor is inhibited by a specific inhibitor, tissue factor pathway inhibitor (TFPI), synthesized and expressed by endothelial cells in the microcirculation. 50$80 \%$ of TFPI forms the endothelial pool, $10-50 \%$ circulates in plasma and less than $2.5 \%$ is found in thrombocytes ${ }^{16}$. TFPI prevents excessive thrombin formation by binding to activated factor $\mathrm{X}$ in the TF/FVIIa/FXa complex ${ }^{17,18}$. Another tissue factor inhibitor in this complex is antithrombin ${ }^{19}$.

\section{TISSUE FACTOR - REGULATION OF ITS EXPRESSION}

The integral role of TF during coagulation activation due to the disruption of the integrity of the vascular network caused by trauma has long been accepted. Today, a wide range of other biological effects of TF is under study. Hyperexpression of TF with subsequent shift of the hemostatic equilibrium towards hypercoagulation has been observed in cardiovascular diseases, diabetes, metabolic syndrome, inflammatory conditions, generalization of malignant diseases, and also in cases of pregnancy complications such as repeated miscarriages and preeclampsia $^{20,21}$. In all of these clinical situations, two basic pathogenic mechanisms associated with the activation of TF apply and they potentiate each other: thrombotization and inflammation ${ }^{1}$. Thrombin as a direct consequence of coagulation activation in these pathological conditions, leads to the formation of fibrin and activates thrombocytes and TAFI (thrombin activated fibrinolysis inhibitor) by signal induction with subsequent suppression of PA (plasminogen activator) and overexpression of PAI (plasminogen activator inhibitor) (ref. ${ }^{22-24}$ ). In addition, thrombin activates an entire group of protease-activated receptors (PAR), which leads to thrombocyte activation (PAR-1) and induces inflammation by producing interleukins, adhesion molecules, growth factors, serotonin, histamine and other inflammation mediators in cells, which amass at the thrombotization site (monocytes, macrophages, granulocytes, thrombocytes) (ref., ${ }^{3,25-27}$ ). The inflammation mediators induced by thrombotization lead to further coagulation activation by suppressing natural coagulation inhibitors - antithrombin, activated protein C and TFPI (ref. ${ }^{28,29}$ ). Products of activation of TF - F IIa, F VIIa, Xa - cause further overexpression of tissue factor, which closes the vicious circle: thrombosis-inflammationthrombosis, linked by tissue factor ${ }^{30,31}$.

Research on the biological functions of TF has revealed both situations associated with overexpression of $\mathrm{TF}$, as well as mediators and pharmaceuticals capable of influencing TF. Expression of TF is decreased by anticoagulants (for ex. LMWH, heparin, hirudin, antithrombin), metformin, ACE inhibitors, COX inhibitors, inhibitors of HMG-CoA reductase and others. ; In contrast, increase in TF is found after oral contraceptives, dexamethazone,

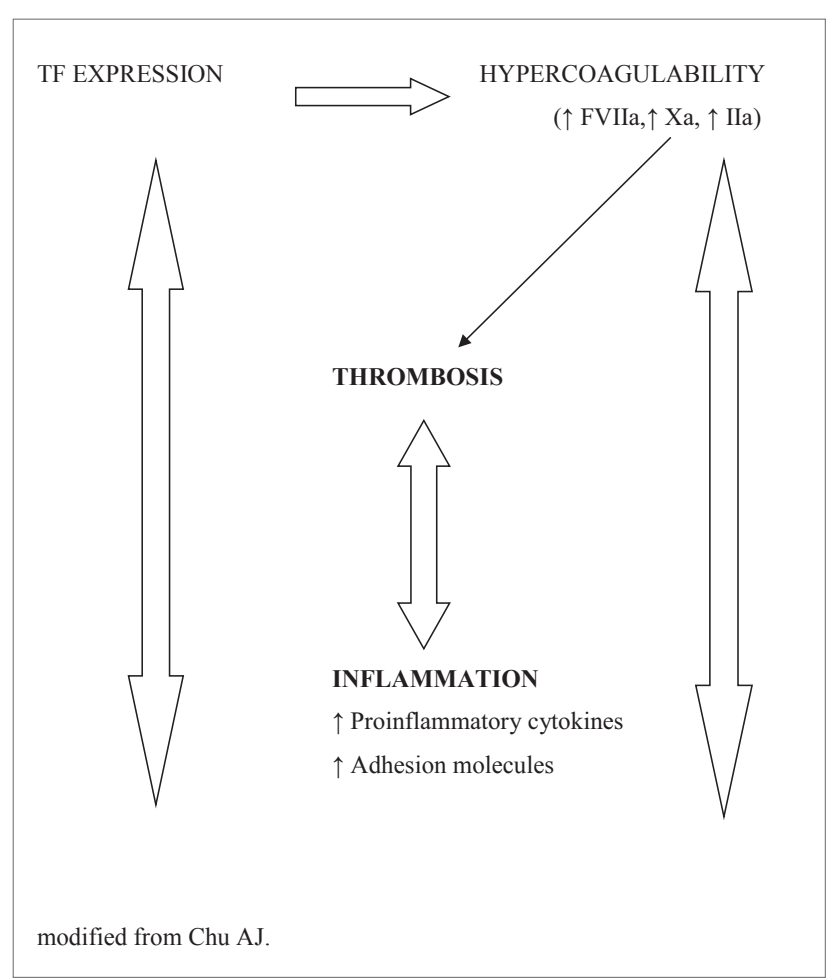

Fig. 1. "Vicious circle" thrombosis - inflammation - thrombosis. 
estrogen, in cigarette smokers and in hyperhomocysteinemia $^{32-48}$.

\section{TISSUE FACTOR - ITS ROLE DURING NORMAL PREGNANCY AND THE DEVELOPMENT OF PREECLAMPSIA}

Tissue factor is a key element for normal gestation, especially in the first trimester. Endometrial stromal cells are known to prevent hemorrhage during invasion of the trophoblast during implantation, also in part due to increased expression of tissue factor ${ }^{49}$. It seems that the large amount of TF and resulting physiological hypercoagulation state in uteroplacental circulation is essential for maintaining local hemostatic equilibrium on the maternal and fetal side ${ }^{50}$. Tissue factor also plays a significant role in embryogenesis, shown by the results of research on mouse embryos with TF deficit, which showed lethal hemorrhaging during embryonic development and dysfunctional development of embryonic vascular structures independent of the coagulation function of TF ( ref. $^{51-53}$ ).

Preeclampsia is one of the most serious causes of maternal and neonatal morbidity and mortality with a prevalence of $6-8 \%$ of pregnancies ${ }^{54}$. It is a disease that develops from placental ischemia caused by an abnormal immune response of the maternal organism to fetal tissue that expresses antigens of paternal origin. The foundation of this clinical entity is endothelial damage due to defective invasion of the fetal trophoblast into spiral arterioles of the maternal circulation ${ }^{54}$. In pregnancy complicated by preeclampsia, there is insufficient invasion of trophoblast vessels into the uterine mucosa, which leads to placental ischemia. Patients develop multiple microthrombi in placental tissue causing the release of fragments of syncitiotrophoblasts and vasoactive mediators into the maternal circulation. Placental ischemia-induced release of circulating factors is part of a systemic inflammatory response which leads to the alteration of vascular reactivity and causes damage to endothelial cells which become the target tissue of these changes ${ }^{55}$. Generalized endothelial dysfunction causes the clinical symptoms of preeclampsia which are hypertension, increased vascular permeability causing proteinuria, coagulopathy and damage to various organs as a result of thrombotic microangiopathy. A higher risk for future cardiovascular morbidity was found in women who had preeclampsia during pregnancy, which supports the idea of lasting endothelial dysfunction even after pregnancy and the cessation of preeclampsia symptoms $^{54,56,57}$.

In women with preeclampsia, increased signs of a hypercoagulation condition were found ${ }^{58,59}$. These changes had often already occurred prior to the onset of clinical symptoms. In pregnancies complicated by preeclampsia, increased levels of coagulation factor VIII, von Willebrand factor, thrombin-anti-thrombin, d-dimer complex, soluble fibrin and thrombomodulin have been found ${ }^{60.65}$. Other confirmed changes include the activation of granulocytes and monocytes and the associated release of inflamma- tory cytokines ${ }^{66,67}$. The results of a large number of studies on the role of tissue factor and its primary inhibitor, TFPI, are ambiguous and often conflicting. Both increased ${ }^{6871}$, as well as unchanged ${ }^{72-74}$ levels of plasma TF in preeclampsia compared to normal pregnancy have been reported According to various studies, the level of plasma TFPI was also unchanged ${ }^{70,72}$, increased ${ }^{69,74,75}$ or decreased ${ }^{71}$. The conflicting data appear to reflect study design and methods issues, rendering comparison problematic. Overall, the results of the studies found in the literature search together with knowledge of the structure and biological effects of TF indicate that measuring the level of plasma TF/TFPI is not ideal for determining the actual levels of TF in the uteroplacental circulation.

Current information suggests that endothelial dysfunction is the trigger for preeclampsia. In this regard, aspirin may be an effective prophylaxis. Meta analysis of 34 randomized trials (Bujold et al.) confirmed that low-dose aspirin administration in early phases of gravidity (starting from the $16^{\text {th }}$ week of pregnancy or earlier) significantly reduces the incidence of preeclampsia ${ }^{76}$. At present, the use of aspirin in this indication is recommended for pregnant women with risk factors of preeclampsia.

Further research will be necessary in this field, for example measuring the expression of tissue factor on monocytes using flowcytometry and comparing the development of this expression during normal pregnancy and pregnancy complicated by preeclampsia looks promising. Another interesting possibility is immunohistochemical determination of the level of expression of tissue factor directly in placental tissue.

\section{ACKNOWLEDGEMENTS}

This study was supported by the Internal Grant Agency (IGA NT 14394-3/2013) of the Czech Republic Ministry of Health.

Author contributions: All authors contributed equally to preparing the manuscript.

Conflict of interest statement: The authors state that there are no conflicts of interest regarding the publication of this article.

\section{REFERENCES}

1. Chu AJ. Tissue Factor, Blood Coagulation, and Beyond: An Overview. International Journal of Inflammation 2011;Article ID 367284, 30 pages, doi:10.4061/2011/367284

2. Petersen LC, Valentin S, Hedner U. Regulation of the extrinsic pathway systém in health and disease: the role of factor VII a and tissue factor pathway inhibitor. Thrombosis Research 1995;79(1):1-47.

3. Chu AJ. Tissue factor mediates inflammation. Archives of Biochemistry and Biophysics 2005;440(2):123-32.

4. Kittur FS, Manithody C, Morrisey JH, Rezaie AR. The cofactor function of the $\mathrm{N}$-terminal domain of tissue factor. Journal of Biological Chemistry 2004;279(38):39745-9.

5. Østerud B, Bjørklid E. Sources of tissue factor. Seminars in Thrombosis and Hemostasis 2006;32(1):11-23.

6. Drake TA, Morrisey JH, Edgington TS. Selective cellular expression of tissue factor in human tissues. Am J Pathol 1989;134:1087-97. 
7. Flössel C, Luther T, Müller M, Albrecht S, Kasper M. Immunohistochemical detection of tissue factor (TF) in paraffin sections of routinely fixed human tissue. Histochemistry 1994;101:448-53.

8. Key NS, Mackman N. Tissue factor and its measurement in whole blood, plasma and microparticles. Seminars in Thrombosis and Hemostasis 2010;36(8):865-75.

9. Muller I, Klocke A, Alex M, Kotzch M, Luther T, Morgenstern E, Zieseniss S, Zahler S, Preissner K, Engelmann B. Intravascular tissue factor iniciates coagulation via circulating microvesicles and plateles. FASEB Journal 2003;17:476-8.

10. Berckmans RJ, Neiuwland R, Boing AN, Romijn FP, Hack CE, Sturk A. Cell derived microparticles circulate in healthy humans and support low grade thrombin generation. Thromb Haemost 2001;85:639-46.

11. Albrecht S, Kotzch M, Siegert G, Luther T, Grossmann H, Grosser M Müller M. Detection of circulating tissue factor aand factor VII in a normal population. Thromb Haemost 1996;75:772-7.

12. Carlsson K, Freskgard, PO, Persson E, Carlsson U, Svensson M. Probing the interface between factor $\mathrm{X}$ a and tissue factor in the quaternary complex tissue factor-factor VIla-factor Xa-tissue factor pathway inhibitor. Eur J Biochem 2003;270(12):2576-82.

13. Mackman N. Role of Tissue Factor in Haemostasis, Thrombosis, and Vascular Development. Arterioscler Thromb Vasc Biol 2004; 24:101522.

14. Belting M, Ahamed J, Ruf W. Signaling of the tissue factor coagulation pathway in angiogenesis and cancer. Arteiroscler Thromb Vasc Biol 2005;25:1545-50.

15. Rosen ED, Chan JCY, Idusogie E, Clotman F, Vlasuk G, Luther T, Jalbert LR, Albrecht S, Zhong L, Lissens A, Schoonjans L, Moons L, Collen D, Castellino FJ, Carmeliet P. Mice lacking factor VII develop normally but suffer fatal perinatal bleeding. Nature 1997;390:290-4.

16. Sandset PM. Tissue factor pathway inhibitor (TFPI) - an update. Haemostasis 1996;26:154-65.

17. Broze Jr GJ. Tissue factor pathway inhibitor. Thromb Haemost 1995;74:90-3.

18. Osterud B, Bajaj MS, Bajaj SP. Sites of tissue factor pathway inhibitor (TFPI) and tissue factor expression under physiological and pathological conditions. Thromb Haemost 1995;73:873-5.

19. Van Hinsbergh VWM: Endothelium - role in regulation of coagulation and inflammation. Semin Imunopathol 2012;34(1):93-106.

20. Marmur JD, Thiruvikraman SV, Fyfe BS, Guha A, Sharma SK, Ambrose JA, Fallon JT, Nemerson Y, Taubman MB. Identification of active tissue factor in human coronary atheroma. Circulation 1996;94:1226-32.

21. Taubman MB, Fallon JT, Schecter AD, Giesen P, Mendlowitz M, Fyfe BS, Marmur JD, Nemerson Y. Tissue factor in the pathogenesis of atherosclerosis. Thromb Haemost 1997;78:200-4.

22. Bouma BN, Meijers JC. New insights into factors affecting clot stability: a role for thrombin activatable fibrinolysis inhibitor (TAFI; plasma procarboxypeptidase B, plasma procarboxypeptidase U, procarboxypeptidase R). Seminars in Hematology 2004;41(1),S1:13-9.

23. Guimarães AHC, Rijken DC. Thrombin activatable fibrinolysis inhibitor (TAFI) affects fibrinolysis in a plasminogen activator concentration-dependent manner. Study of seven plasminogen activators in an internal clot lysis model. Journal of Thrombosis and Haemostasis 2004;91(3):473-9.

24. Mandl-Weber S, Haslinger B, Sitter T. Thrombin upregulates production of plasminogen activator inhibitor type 1 in human peritonea mesothelial cells. Peritoneal Dialysis International 1999;19(4):319-24.

25. Chambers RC, Laurent GJ. Coagulation cascade proteases and tissue fibrosis. Biochemical Society Transactions 2002;30(2):194-200.

26. Ramachandran R, Hollenberg MD. Proteinases and signalling: pathophysiological and therapeutic implications via PARs and more. British Journal of Pharmacology 2008;153(1):S263-82.

27. Riewald M, Ruf W. Mechanistic coupling of protease signaling and initiation of coagulation by tissue factor. Proceedings of the National Academy of Sciences of the United States of America 2001;98(14):7742-7.

28. White B, Perry D. Acquired antithrombin deficiency in sepsis. British Journal of Haematology 2001;112(1):26-31.

29. Asakura H, Ontachi $Y$, Mizutani T, Kato M, Ito T, Saito M, Morishita E, Yamazaki M, Aoshima K, Takami A, Yoshida T, Suga Y, Miyamoto $\mathrm{K}$, Nakao S. Decreased plasma activity of antithrombin or protein $C$ is not due to consumption coagulopathy in septic patients with disseminated intravascular coagulation. European Journal of Haematology 2001;67(3):170-5.
30. Camerer E, Røttingen J-A, Gjernes E, Larsen K, Skartlien AH, Iversen JG, Prydz H. Coagulation factors VIla and Xa induce cell signaling leading to up- regulation of the egr-1 gene. Journal of Biological Chemistry 1999;274(45):32225-33.

31. Chen D, Riesbeck K, McVey JH, Kemball-Cook G, Tuddenham EG, Lechler RI, Dorling A. Human thrombin and FXa mediate porcine endothelial cell activation; modulation by expression of TFPI-CD4 and hirudin-CD4 fusion proteins. Xenotransplantation 2001;8(4):258-65.

32. Lindmark $E$, Siegbahn A. Tissue factor regulation and cytokine expression in monocyte-endothelial cell co-cultures: effects of a statin, an ACE-inhibitor and a low-molecular-weight heparin. Thrombosis Research 2002;108(1):77-84.

33. Pernerstorfer $T$, Hollenstein $U$, Hansen JB, Knechtelsdorfer $M$, Stohlawetz P, Graninger W, Eichler HG, Speiser W, Jilma B. Heparin blunts endotoxin-induced coagulation activation. Circulation 1999;100(25):2485-90.

34. Gori AM, Pepe G, Attanasio M, Falciani M, Abbate R, Prisco D, Fedi S, Giusti B, Brunelli T, Giusti B, Brunelli T, Comeglio P, Gensini GF, Neri Serneri GG. Tissue factor reduction and tissue factor pathway inhibitor release after heparin administration. Journal of Thrombosis and Haemostasis 1999;81(4):589-93.

35. Gertz SD, Fallon JT, Gallo R, Taubman MB, Banai S, Barry WL, Gimple LW, Nemerson Y, Thiruvikraman S, Naidu SS, Chesebro JH, Fuster V, Sarembock IJ, Badimon JJ. Hirudin reduces tissue factor expression in neointima after ballon injury in rabbit femoral and porcine coronary arteries. Circulation 1998;98:580-7.

36. Hölschermann $H$, Bohle RM, Schmidt $H$, Zeller H, Fink L, Stahl $U$, Grimm H, Tillmanns $\mathrm{H}$, Haberbosch W. Hirudin reduces tissue factor expression and attenuates graft arteriosclerosis in rat cardiac allografts. Circulation 2000;102(3):357-63.

37. Souter PJ, Thomas S, Hubbard AR, Poole S, Römisch J, Gray E. Antithrombin inhibits lipopolysaccharide-induced tissue factor and interleukin- 6 production by mononuclear cells, human umbilical vein endothelial cells, and whole blood. Critical Care Medicine 2001;29(1):134-9.

38. Arai M, Uchiba M, Komura H, Mizuochi Y, Harada N, Okajima K Metformin, an antidiabetic agent, suppresses the production of tumor necrosis factor and tissue factor by inhibiting early growth response factor- 1 expression in human monocytes in vitro. Journal of Pharmacology and Experimental Therapeutics 2010;334(1):20613.

39. Napoleone E, Di Santo A, Camera M, Tremoli E, Lorenzet R. Angiotensin-converting enzyme inhibitors downregulate tissue factor synthesis in monocytes. Circulation Research 2000;86(2):139-43.

40. Steffel J, Hermann M, Greutert H, Gay S, Lüscher TF, Ruschitzka F, Tanner FC. Celecoxib decreases endothelial tissue factor expression through inhibition of c-Jun terminal $\mathrm{NH}_{2}$ kinase phosphorylation. Circulation 2005;111(13):1685-89.

41. Kunieda $Y$, Nakagawa K, Nishimura H, Kato H, Ukimura N, Yano $S$ Kawano H, Kimura S, Nakagawa M, Tsuji H. HMG CoA reductase inhibitor suppresses the expression of tissue factor and plasminogen activator inhibitor-1 induced by angiotensin II in cultured rat aortic endothelial cells. Thrombosis Research 2003;110(4):227-34.

42. Wang HY, Yang YM, Zhuang Y, Chen HN, Wan YL, Huang YT. The effect of celecoxib on tissue factor expression in pancreatic cancer cells. Chinese Medical Journal 2007;120(20):1753-6.

43. Wei JL, Cui HM, Ma CY. Simvastatin inhibits tissue factor and plasminogen activator inhibitor- 1 secretion by peripheral blood mononuclear cells in patients with primary nephrotic syndrome. European Journal of Medical Research 2007;12(5):216-21.

44. Hölschermann H, Terhalle HM, Zakel U, Maus U, Parviz B, Tillmanns $\mathrm{H}$, Haberbosch W. Monocyte tissue factor expression is enhanced in women who smoke and use oral contraceptives. Journal of Thrombosis and Haemostasis 1999;82(6):1614-20.

45. Reddy KV, Bhattacharjee G, Schabbauer G, Hollis A, Kempf K, Tencati M, O'Connell M, Guha M, Mackman N. Dexamethasone enhances LPS induction of tissue factor expression in human monocytic cells by increasing tissue factor mRNA stability. Journal of Leukocyte Biology 2004;76(1):145-51.

46. Henrikson KP, Greenwood JA, Pentecost BT, Jazin EE, Dickerman HW. Estrogen control of uterine tissue factor messenger ribonucleic acid levels. Endocrinology 1992;130(5):2669-74

47. Matetzky S, Tani S, Kangavari S, Dimayuga P, Yano J, Xu H, Chyu KY, Fishbein MC, Shah PK, Cercek B. Smoking increases tissue factor ex- 
pression in atherosclerotic plaques: implications for plaque thrombogenicity. Circulation 2000;102(6):602-4.

48. Dardik R, Varon D, Tamarin I, Zivelin A, Salomon O, Shenkman B, Savion N. Homocysteine and oxidized low density lipoprotein enhance platelet adhesion to endothelial cells under flow conditions: distinct mechanisms of thrombogenic modulation. Journal of Thrombosis and Haemostasis 2000;83(2):338-44.

49. Lockwood CJ, Krikun G, Runic R, Schwartz LB, Mesia AF, Schatz F. Progestin epidermal growth factor regulation of tissue factor expression during decidualization of human endometrial stromal cells. J Clin Endocrinol Metab 2000;85:297-301.

50. Higgins JR, Walshe JJ, Darling MR, Norris L, Bonnar J. Haemostasis in the uteroplacental and peripheral circulation in normotensive and pre-eclamptic pregnancies. Am J Obstet Gynecol 1998;179:520-6.

51. Carmeliet $P$, Mackman N, Moons $L$, Luther $T$, Gressens $P$, Van Vlaenderen I, Demunck H, Kasper M, Breier G, Evrard P, Müller M Risau W, Edgington T, Collen D. Role of tissue factor in embryonic blood vessel development. Nature 1996;383:73-5.

52. Bugge TH, Xiao Q, Kombrinck KW, Flick MJ, Holmback K, Danton MJS, Colbert MC, Witte DP, Fujikawa K, Davie EW, Degen JL. Fata embryonic bleeding events in mice lacking tissue factor, the cell associated initiator of blood coagulation. Proc Natl Acad Sci USA 1996;93:6258-63.

53. Toomey JR, Kratzer KE, Lasky NM, Stanton JJ, Broze Jr GJ. Targeted disruption of the murine tissue factor gene results in embryonic lethality. Blood 1996;88:1583-7.

54. Lyall F, Belfort M. Pre-eclampsia. Etiology and clinical practice. Cambridge University Press 2007. P. 3-31,325-335,369.

55. Šimetka O, Brychtová P, Procházková J, Procházka M. Laboratorn změny aktivace endotelu u syndromu HELLP. Gynekolog 2008;2:48 53.

56. Magee LA. Pre-eclampsia and increased cardivascular risk. Br Med J 2007;335:945-6.

57. Bellamy L, Casas JP, Hingorani AD, Williams DJ. Pre-eclampsia and risk of cardiovascular disease and cancer in later life: systematic review and metaanalysis. Br Med J 2007;335:974-7.

58. He S, Bremme K, Blomback M. Acquired deficiency of antithrombin in association with a hypercoagulable state and impaired function of liver and/or kidney in preeclampsia. Blood Coagul Fibrinolysis 1997;8:232-8.

59. DG M. Hematologic evidence of disseminated intravascular coagulation in Pre-eclampsia. Obstet Gynecol Surv 1972;399-417.

60. Howie PW, Prentice CR, McNicol GP. Coagulation, fibrinolysis and platelet function in pre-eclampsia, essential hypertension and placental insufficiency. J ObstetGynaecol Br Commonw 1971;78:992.

61. Redman CWG, Denson KWE, Beilin LJ, Bolton FG, Stirrat GM. FactorVIII consumption in pre-eclampsia. Lancet 1977;2:1249-52.

62. Aznar J, Gilabert J, Estelles A, Espana F. Fibrinolytic-activity and protein-c in preeclampsia. Thromb Haemost 1986;55:314-7.
63. Schjetlein R, Abdelnoor M, Haugen G, Husby H, Sandset PM, Wisloff F. Hemostatic variables as independent predictors for fetal growth retardation in preeclampsia. Acta Obstet Et Gynecol Scand 1999;78:191-7.

64. Higgins JR, Walshe JJ, Darling MRN, Norris L, Bonnar J. Hemostasis in the uteroplacental and peripheral circulations in normotensive and pre-eclamptic pregnancies. Am J Obstet Gynecol 1998;179:520-6.

65. Dusse LM, Carvalho MG, Getliffe K, Voegeli D, Lwaleed BA, Cooper AJ. Increased circulating thrombomodulin levels in pre-eclampsia. Clin Chim Acta 2008;387:168-71.

66. Vince GS, Starkey PM, Austgulen R, Kwiatkowski D, Redman CWG. Interleukin-6, tumor-necrosis-factor and soluble tumor-necrosisfactor receptors in women with preeclampsia. Br J Obstet Gynaecol 1995; 102:20-5.

67. Dusse LM, Rios DRA, Pinheiro MB, Cooper AJ, Lwaleed BA. Preeclampsia: Relationship between coagulation, fibrinolysis and inflammation. Clinica Chimica Acta 2011:412:17-21.

68. Di Paolo S, Volpe P, Grandaliano G. Increased placental expression of tissue factor is associated with abnormal uterine and umbilical Doppler waveforms in severe preeclampsia with fetal growth restriction. J Nephrol 2003;16:650-7.

69. Erez O, Romero R, Hoppensteadt D, Than NG, Fareed J, Mazaki-Tovi S, Espinoza J, Chaiworapongsa T, Kim SS, Yoon BH, Hassan SS, Gotsch F, Friel L, Vaisbuch E, Kusanovic JP. Tissue factor and its natural inhibitor in pre-eclampsia and SGA. J Matern Fetal Neonatal Med 2008;21:855-69.

70. Rousseau A, Favier R, Van Dreden P. Elevated circulating soluble thrombomodulin activity, tissue factor activity and circulating procoagulant phospholipids: new and useful markers for pre-eclampsia? Eur J Obstet Gynecol Reprod Biol 2009;146:46-9.

71. Teng Y, Jiang R, Lin Q, Ding C, Ye Z. The relationship between plasma and placental tissue factor, and tissue factor pathway inhibitors in severe pre-eclampsia patients. Thromb Res 2010;126:e41-5.

72. Dusse LM, Carvalho MG, Getliffe K, Voegeli D, Cooper AJ, Lwaleed BA Total plasma tissue factor pathway inhibitor levels in pre-eclampsia. Clin Chim Acta 2008;388:230-2.

73. Lopez-Ramirez Y, Carvajal Z, Arocha-Pinango CL. Hemostatic system parameters of placental extracts in normal pregnancy and severe preeclampsia. Invest Clin 2006;47:233-40.

74. Godoi LC, Gomes KB, Alpoim PN, Carvalho MG, Lwaleed BA, Dusse LMSA. Preeclampsia: the role of tissue factor and tissue factor pathway inhibitor. J Thromb Thrombolysis 2012;34:1-6.

75. Schjetlein R, Abdelnoor M, Haugen G, Husby H, Sandset PM, Wisløff F. Hemostatic variables as independent predictors for fetal growth retardation in preeclampsia. Acta Obstet Gynecol Scand 1999;78:1917.

76. Bujold E, Roberge S, Lacasse $\mathrm{Y}$, Bureau M, Audibert F, Marcoux S, Forest JC, Giguere Y. Prevention of Preeclampsia and Intrauterine Growth Restriction With Aspirin Started in Early Pregnancy. Obstetrics \& Gynecology 2010;116(2):402-14 